\title{
Distribution of Buxbaumia viridis (Moug. ex Lam. et DC.) Brid. ex Moug. et Nestl. (Bryophyta) in Montenegro
}

\author{
SneŽAna Dragićević ${ }^{*}$, BeÁta PAPP ${ }^{2}$, Peter ERZBERger ${ }^{3}$ \\ ${ }^{1}$ Natural History Museum of Montenegro, Trg Vojvode Bećir Bega Osmanagića 16, \\ 81000 Podgorica, Montenegro \\ ${ }^{2}$ Hungarian Natural History Museum, Botanical Department, Budapest, \\ Pf 222. H-1476, Hungary \\ ${ }^{3}$ Belziger Str. 37, D-10823 Berlin, Germany
}

\begin{abstract}
The present paper is a contribution to the knowledge of the distribution of the moss species Buxbaumia viridis in Montenegro. The records are from 14 known sites at elevations over $1300 \mathrm{~m}$ a.s.l. in the northern and north-eastern parts of the country. Population size is remarkable in Durmitor National Park at Crno jezero lake, where sporophytes can be found on ca 50 tree trunks.
\end{abstract}

Keywords: moss, Buxbaumia viridis, distribution, Montenegro

\section{Introduction}

The genus Buxbaumia Hedw. is represented by two species in Europe: Buxbaumia aphylla Hedw. and Buxbaumia viridis (Moug. ex Lam. et DC.) Brid. ex Moug. et Nestl. (HiLl et al. 2006), both of which occur in Montenegro. According to SABOvLJEvić and STEVANOvić (2000), Buxbaumia aphylla Hedw. was recorded in 1998 at two localities within the Durmitor National Park, while Buxbaumia viridis was found much earlier in the same area by MARTINČIČ (1964).

Buxbaumia viridis is a boreal-montane species (DüLL 1984). It is sparsely distributed throughout the northern hemisphere, from Europe to southwest Asia and China to western North America (SMiтh 2004). It has been recorded from all Southeast European countries except the European part of Turkey (SABOVLJEvić et al. 2008).

Buxbaumia viridis is found growing on well-decayed wood in constantly humid forests, sheltered or shaded places, rarely on humus-rich acidic soil. During most of the year it lives as protonema in the substrate and can usually be recognized only, when sporophytes are

* Corresponding author, e-mail: sneza.dragicevic@t-com.me Copyright ${ }^{\circledR} 2012$ by Acta Botanica Croatica, the Faculty of Science, University of Zagreb. All rights reserved. 
produced. These can be found singly or in small groups on the surface of decaying trunks. The sporophyte is of remarkable size; the seta $(5-10 \mathrm{~mm}$ long) supports a large asymmetrical capsule, which when mature bears an »indusium «, (a characteristic feature of this species, expressed in its synonym Buxbaumia indusiata). The indusium is formed by the cuticle of the capsule when it splits longitudinally and peels back, persisting in large, ragged pieces (SмITH 2004).

The species is endangered by forestry practices, especially by clear-cutting huge areas of forest, and other forms of commercial exploitation that have reduced the extent of old-growth forests, the number of well-decayed logs, and changes in the microclimate.

Buxbaumia viridis appears on the Red List of most countries where it occurs. The European Committee for the Conservation of Bryophytes rates Buxbaumia viridis as Vulnerable in Europe (STEWART 1995). The species is listed in Annex II of the EC Habitats and Species Directive and in Appendix I of the Council of Europe Bern Convention. It is treated as Critically Endangered in the Bryophyte Red List of Serbia and Montenegro (SABovljević et al. 2004). The moss is protected by law in Montenegro, but seems to be at extremely high risk of extinction owing to its fragmented distribution, and small total number of plants.

\section{Study area}

The study area is located in the northern and north-eastern parts of Montenegro. It includes 8 mountainous regions: the Bjelasica Mts, Durmitor Mts, Hajla Mts, Komovi Mts, Ljubišnja Mts, Prokletije Mts, Sinjajevina Mts and Visitor Mts (Fig. 1). Some characteristics about the regions investigated are given in table 1 .

\section{Materials and methods}

Our investigations were carried out mainly in the high mountain regions of Montenegro between 2004-2009. In each locality, in order to detect the presence of the species, we searched for large, well-decayed trunks in old-growth conifer, beech or deciduous (mixed) forests. The specimens collected are deposited in the Herbarium of the Natural History Museum of Montenegro, the Hungarian Natural History Museum, Budapest (BP) and in the Herbarium of Botanisches Museum Berlin-Dahlem (B).

In order to estimate the threat status according to the new IUCN categories (IUCN 1994, 2001) the following criteria should be taken into consideration (HALLINGBÄCK et al. 1998):

A. Large decline (Major population decline observed, estimated, inferred or suspected in the last 10 years or 3 generations, whichever is the longer)

B. Restricted area of occupancy, few localities, decline

C. Small population and decline, and

D. Very small or restricted populations

For the estimation of population size of Buxbaumia viridis the trees colonized can be counted as individuals, because the destruction of the substrate will affect all plants growing on it (HALLINGBÄCK et al. 1998). In the field we counted the number of trees on which sporophytes of the species were detected. 


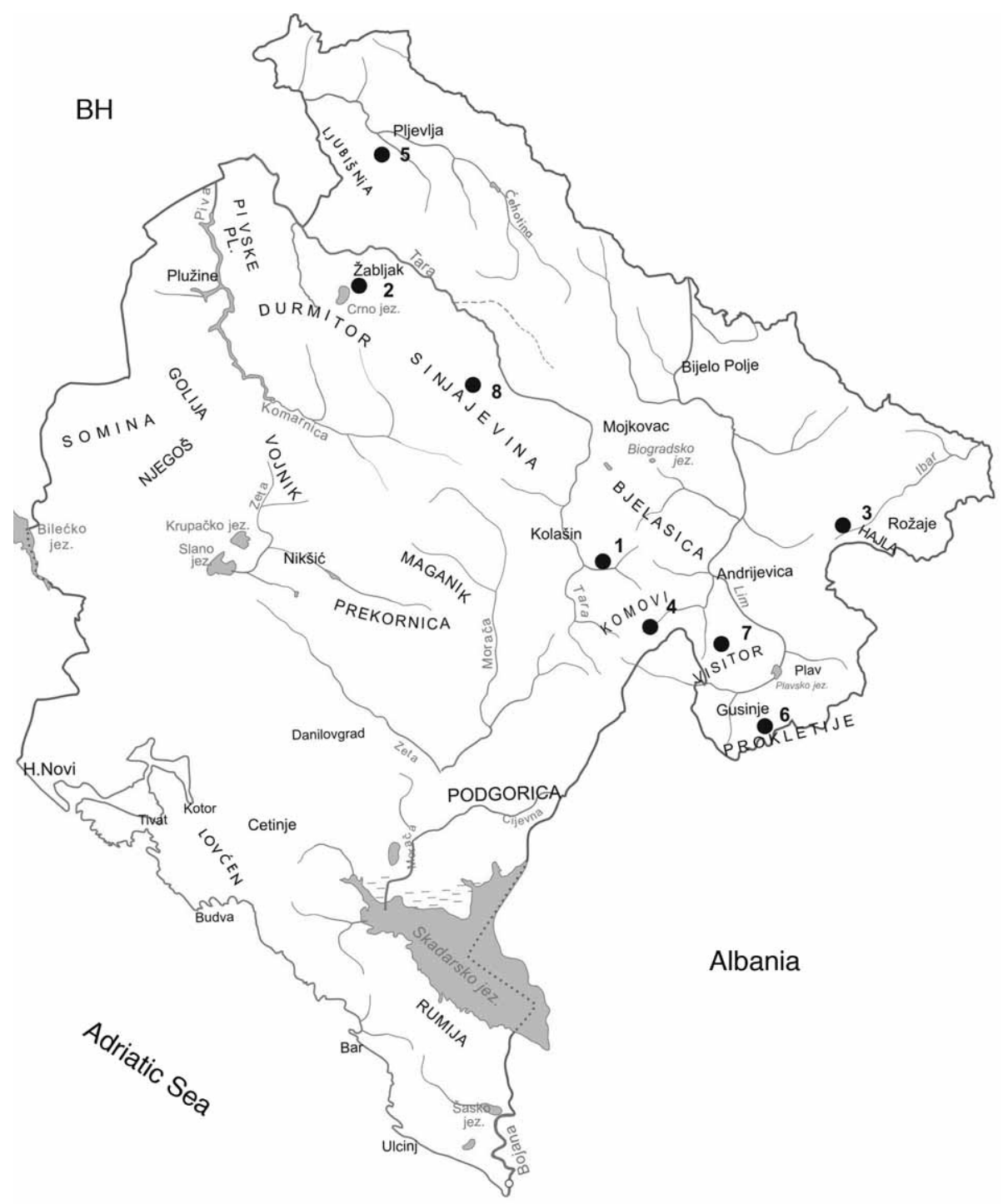

Fig. 1. The distribution of known localities of Buxbaumia viridis in Montenegro (1-Bjelasica Mts; 2-Durmitor Mts; 3-Hajla Mts; 4-Komovi Mts; 5-Ljubišnja Mts; 6-Prokletije Mts; 7-Visitor Mts; 8-Sinjajevina Mts).

\section{Results and discussion}

During our fieldwork in Montenegro, more than 40 years after the first record of Buxbaumia viridis for the country, we found populations on Mt Durmitor as well as in several other mountain areas. The species was collected at 14 localities in on eight mountains in the northern part of the country. The sites were situated at high elevations, over $1300 \mathrm{~m}$ a.s.l., usually in boreal types of forests. 
Tab. 1. Some characteristics about investigated regions.

\begin{tabular}{|c|c|c|c|c|c|c|}
\hline $\begin{array}{l}\text { No in } \\
\text { Fig. } 1\end{array}$ & $\begin{array}{l}\text { Geographical } \\
\text { name }\end{array}$ & Maximum hight (m asl.) & Bedrock & Climate & $\begin{array}{l}\text { Conservational } \\
\text { status }\end{array}$ & Flora, Vegetation \\
\hline 1 & Bjelasica Mts & 2137 m (Crna glava) & Silicate, volcanic cliffs & $\begin{array}{l}\text { Alpine, moderate- } \\
\text { continental-meditter-ranean }\end{array}$ & - & $\begin{array}{l}\text { rich endemic vascular } \\
\text { flora }\end{array}$ \\
\hline 2 & $\begin{array}{l}\text { Durmitor } \\
\text { Mts }\end{array}$ & 2523 m (Bobotov Kuk) & $\begin{array}{l}\text { carbonate, clastic and } \\
\text { siliceous rocks (mostly } \\
\text { Triassic) }\end{array}$ & $\begin{array}{l}\text { Alpine, } \\
\text { moderate-mediter-ranean }\end{array}$ & $\begin{array}{l}\text { National Park, } \\
\text { IPA }\end{array}$ & rich vascular flora \\
\hline 3 & Hajla Mts & $\begin{array}{l}2280 \mathrm{~m} \text { (Dermandoski } \\
\text { greben) }\end{array}$ & $\begin{array}{l}\text { limestone and volcanic } \\
\text { cliffs }\end{array}$ & $\begin{array}{l}\text { Alpine, } \\
\text { moderate-mediter-ranean }\end{array}$ & IPA & $\begin{array}{l}\text { oak and beech forests, } \\
\text { spruce or spruce and } \\
\text { Macedonian pine forests }\end{array}$ \\
\hline 4 & Komovi Mts & 2484 m (Kučki Kom) & limestone & $\begin{array}{l}\text { Alpine, } \\
\text { moderate-mediter-ranean }\end{array}$ & IPA & extensive scree \\
\hline 5 & Ljubišnja Mts & 2238 m (Dernjačišta) & $\begin{array}{l}\text { Limestone } \\
\text { and silicate }\end{array}$ & Alpine & IPA & spruce forest, pastures \\
\hline 6 & Prokletije Mts & 2528 m (Maja Kolata) & limestone & $\begin{array}{l}\text { Alpine, } \\
\text { moderate-mediter-ranean }\end{array}$ & National Park & $\begin{array}{l}\text { rich endemic and relict } \\
\text { vascular flora }\end{array}$ \\
\hline 7 & Sinjajevina Mts & $\begin{array}{l}2277 \mathrm{~m} \text { (Babji zub or } \\
\text { Torna) }\end{array}$ & carbonate & $\begin{array}{l}\text { Mediter-ranean and } \\
\text { continental }\end{array}$ & IPA & rich flora \\
\hline 8 & Visitor Mts & 2211 m (Plana) & limestone & $\begin{array}{l}\text { Alpine, } \\
\text { moderate-mediter-ranean }\end{array}$ & IPA proposed & $\begin{array}{l}\text { mixed thermophi-lous } \\
\text { forests, beach, beach-silver } \\
\text { fir and Macedonian pine } \\
\text { forests; mountain } \\
\text { meadows, cliffs and screes }\end{array}$ \\
\hline
\end{tabular}


The localities were as follows:

Bjelasica Mountain, at Svinjača stream near Jezerine at Kolašin, 4249'49,5", 19³7'06,7" E, ca 1360 m, conifer and deciduous (mixed) forest, on decaying wood, leg. S. Dragićević, B. Papp and P. Erzberger, 18.07.2007.

Durmitor Mountain, Durmitor National Park, around Crno jezero lake at Žabljak, $43^{\circ} 08^{\prime} 52,0^{\prime \prime} \mathrm{N}, 1^{\circ} 05^{\prime} 48,0^{\prime \prime} \mathrm{E}$, ca $1400 \mathrm{~m}$, conifer forest, on decaying trunk, leg. B. Papp and P. Erzberger, 05.10.2004. (PAPP and ERZBERGER 2010) and leg. S. Dragićević 10.07.2007.; by military resort, ca $1400 \mathrm{~m}$, on decaying trunk, leg. S. Dragićević, 10.07.2007.; along

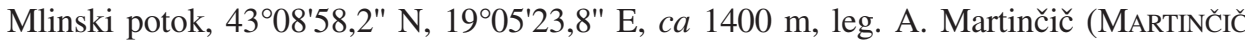
1964) and leg. B. Papp and P. Erzberger, 07.10.2004. (PAPP and ERZBERGER 2010); around

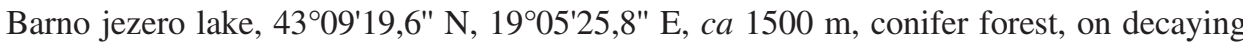
trunk, leg. B. Papp and P. Erzberger, 10.10.2004. (PAPP and ERZBERGER 2010) and leg. S. Dragićević, 12.07.2007.

Hajla Mountain, forest track towards Bandžov, 4247,430' N, 2007,602' E, ca 1336 m, conifer forest (Picea abies), on decaying trunk, leg. S. Dragićević, 28.07.2009.

Komovi Mountain, valley of the Ljubaštica, 4241'44,3" N, 19³3'43,5" E, ca 1770 m, beech forest, on decaying trunk, leg. B. Papp and P. Erzberger, 28.07.2008.

Ljubišnja Mountain, near Pljevlja, ca 1650 m, conifer forest (Picea abies), on decaying trunk, leg. S. Dragićević, 26.08.2007.; Kosanica, near Pljevlja, 4310'39,6" N, 19¹8'13,5" E, ca $1301 \mathrm{~m}$, conifer and deciduous (mixed) forest, on decaying trunk, leg. S. Dragićević, 07.07.2011.

Prokletije Mountains, along the road from Zastan koliba to Maja Jezerce, 42 $29 ' 21,1^{\prime \prime} \mathrm{N}$, 1948'56,7" E, ca 1500 m, on decaying trunk, leg. B. Papp and P. Erzberger, 11.10.2006.; Treća livada in Grebaje valley at Gusinje, 42 30'41,6" N, 1946'40,9" E, ca 1220 m, beech forest, on decaying trunk, leg. B. Papp, 12.10.2006.

Visitor Mountain, along the road to Visitorsko jezero lake, 42³8'07,7" N, 1953'28,3" E, ca 1600 m, leg. B. Papp and P. Erzberger, 09.10.2006.

Sinjajevina Mountain, region Šaranci, along the road to Krš village, 437'16,9" N, 19¹5'39,4" E, ca 1410 m, conifer forest, on decaying trunk, leg. S. Dragićević, 28.06.2007. and 07.07.2011.; Zminičko jezero lake, 43 $06^{\prime} \mathrm{N}, 1^{\circ} 05^{\prime} \mathrm{E}$, ca $1285 \mathrm{~m}$, conifer and deciduous (mixed) forest, on decaying trunk, leg. S. Dragićević, 29.06.2007.

Owing to the threat status of the species, criterion A cannot be applied to the species in Montenegro, as there is insufficient information about earlier occurrences; most of the available data are less than five years old.

The species falls into criterion B, the Vulnerable category, as it was recently recorded in five to ten $10 \mathrm{~km} \mathrm{X} 10 \mathrm{~km}$ squares and found in five to ten localities with most of the populations severely fragmented and in decline.

However, applying criteria C and D places the species in the Critically Endangered category (CR), since the population sizes are small, even the largest population in Durmitor National Park at Crno jezero lake consists of not more than 50 colonized trunks. In the other sites, only a few sporophytes could be found on a small number of trunks.

As the highest IUCN category has to be taken into consideration, we can conclude that, in spite of the new records, Buxbaumia viridis must be treated as a Critically Endangered (CR) species in Montenegro. 


\section{Acknowledgements}

We wish to thank Dr. Vicente Mazimpaka and Dr. Marko Karaman for helpful comments on an earlier version of the manuscript.

\section{References}

DüLL, R., 1984: Distribution of the European and Macaronesian mosses (Bryophytina) I. Bryologische Beitraege 4, 1-109.

Hallingbäck, T., Hodgetts, N., Raeymaekers, G., Schumacker, R., SÉRgio, C., SöderSTRÖM, L., STEWART, N., VÁNA, J., 1998: Guidelines for application of the revised IUCN threat categories to bryophytes. Lindbergia 23, 6-12.

Hill, M. O., Bell, N., Bruggeman-Nannenga, M. A., Brugués, M., Cano, M. J., Enroth, J., Flatberg, K. I., Frahm, J. P., Gallego, M. T., Garilleti, R., Guerra, J., Hedenäs, L., Holyoak, D. T., Hyvönen, J., Ignatov, M. S., Lara, F., MazimpaKa, V., MuÑoz, J., SÖDERSTRÖM, L., 2006: Bryological monograph. An annotated checklist of the mosses of Europe and Macaronesia. Journal of Bryology 28, 198-267.

IUCN, 1994: IUCN Red list categories. International Union for the Conservation of Nature, Gland, Switzerland.

IUCN, 2001: IUCN Red list categories and criteria, 3.1. International Union for the Conservation of Nature Species Survival Commission, Gland, Switzerland and Cambridge, UK.

MARTINČIČ, A., 1964: Contribution to the knowledge of moss flora of Yugoslavia I. Durmitor (Montenegro) (in Slovenian). Biološki Vestnik 12, 43-49.

PApp, B., ERzBerger, P., 2010: Contributions to the bryophyte flora of Durmitor National Park, Montenegro. Nova Hedwigia 138, 147-163.

Sabovljević, M., Stevanović, V., 2000: Buxbaumia aphylla Hedw., new to Montenegro (FR Yugoslavia), and some notes on its ecology. Cryptogamie Bryologie 21, 87-89.

Sabovljević, M., Cvetić, T., Stevanović, V., 2004: Bryophyte red list of Serbia and Montenegro. Biodiversity and Conservation 13, 1781-1790.

Sabovljević, M., Natcheva, R., Dihoru, G., Tsakiri, E., Dragićević, S., ERDaĞ, A., PapP, B., 2008: Check-list of the mosses of SE Europe. Phytologia Balcanica 14, 207-244.

SMith, A. J. E., 2004: The moss flora of Britain and Ireland. University press, Cambridge.

STEWART, N. (ed.), 1995: Red data book of European bryophytes. European Committee for the Conservation of Bryophytes, Trondheim. 